\title{
THE EFFECT OF MELATONIN ON MCF-7 BREAST CANCER CELLS IN VITRO
}

I. Kostoglou-Athanassiou, E. Papageorgiou, A. Armakolas, M. Koutsilieris

Department of Endocrinology, Red Cross Hospital, Athens, Greece

Department of Experimental Physiology, Medical School, University of Athens, Greece

\section{OBJECTIVES}

\section{METHODS}

It has been reported that blind women with disturbed melatonin secretion have a lower incidence of breast cancer. A higher incidence of breast cancer has been reported in women in shift work, in which lower nocturnal melatonin secretion is observed. The anticancer action of melatonin is currently the focus of research interest.

The aim was to study the effect of melatonin on MCF-7 breast cancer cells in vitro.

The effect of melatonin (Sigma-Aldrich) at an initial concentration of 1nM on MCF-7 human breast cancer cells was studied in vitro. MCF-7 human breast cancer cells were incubated for $48 \mathrm{~h}$ at a temperature of $37^{\circ} \mathrm{C}$ with progressively decreasing melatonin concentrations. MCF-7 cells were also incubated for $48 \mathrm{~h}$ with progressively decreasing melatonin concentrations in the presence of the antimitotic agent docetaxel $50 \mathrm{nM}$.

\section{RESULTS}
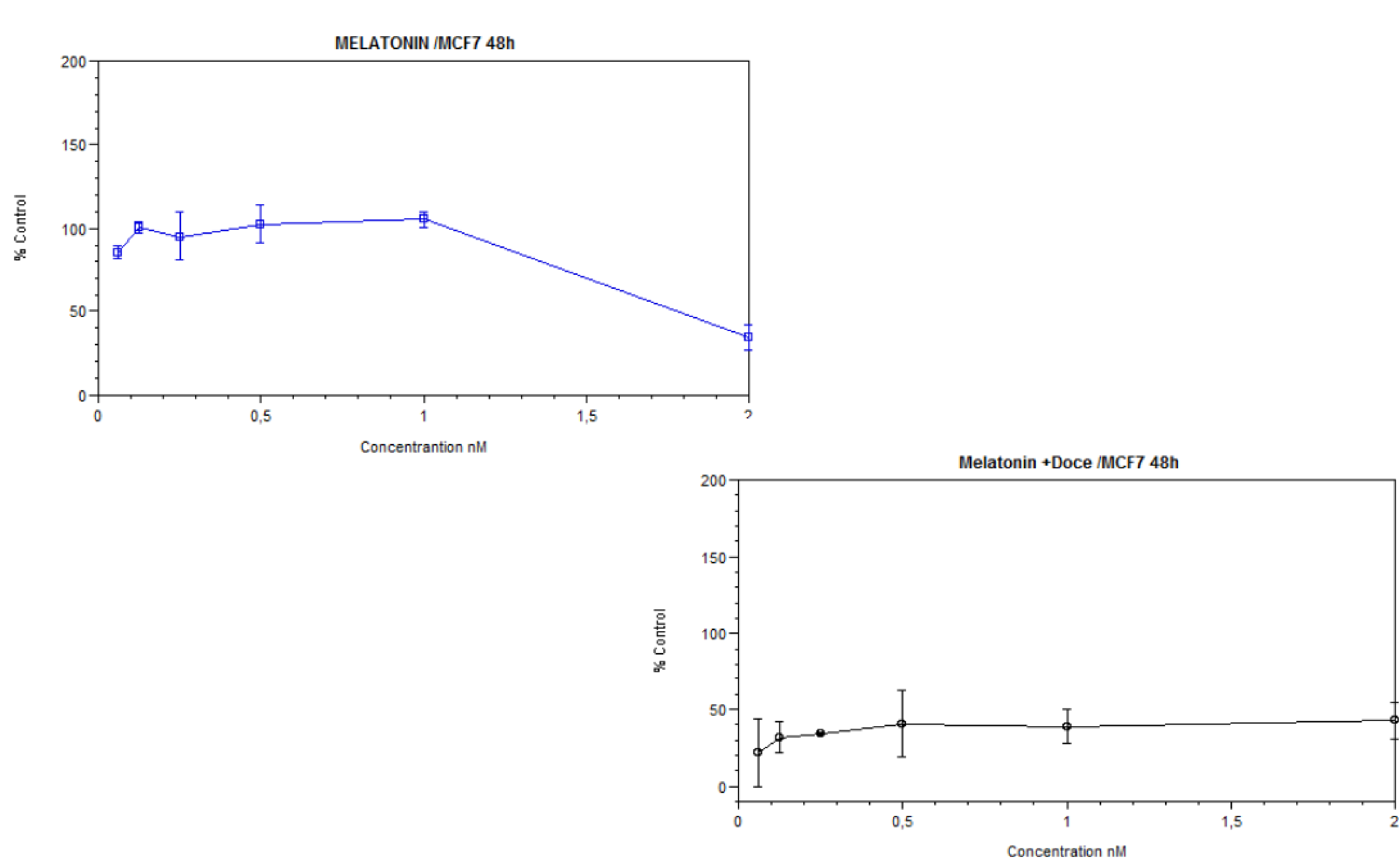

The proliferation of MCF-7 human breast cancer cells was significantly inhibited by melatonin. The antimitotic agent docetaxel significantly inhibited the proliferation of MCF-7 cells. The simultaneous incubation of MCF-7 cells with melatonin and docetaxel had a synergistic inhibitory effect on their proliferation.

\section{CONCLUSIONS}

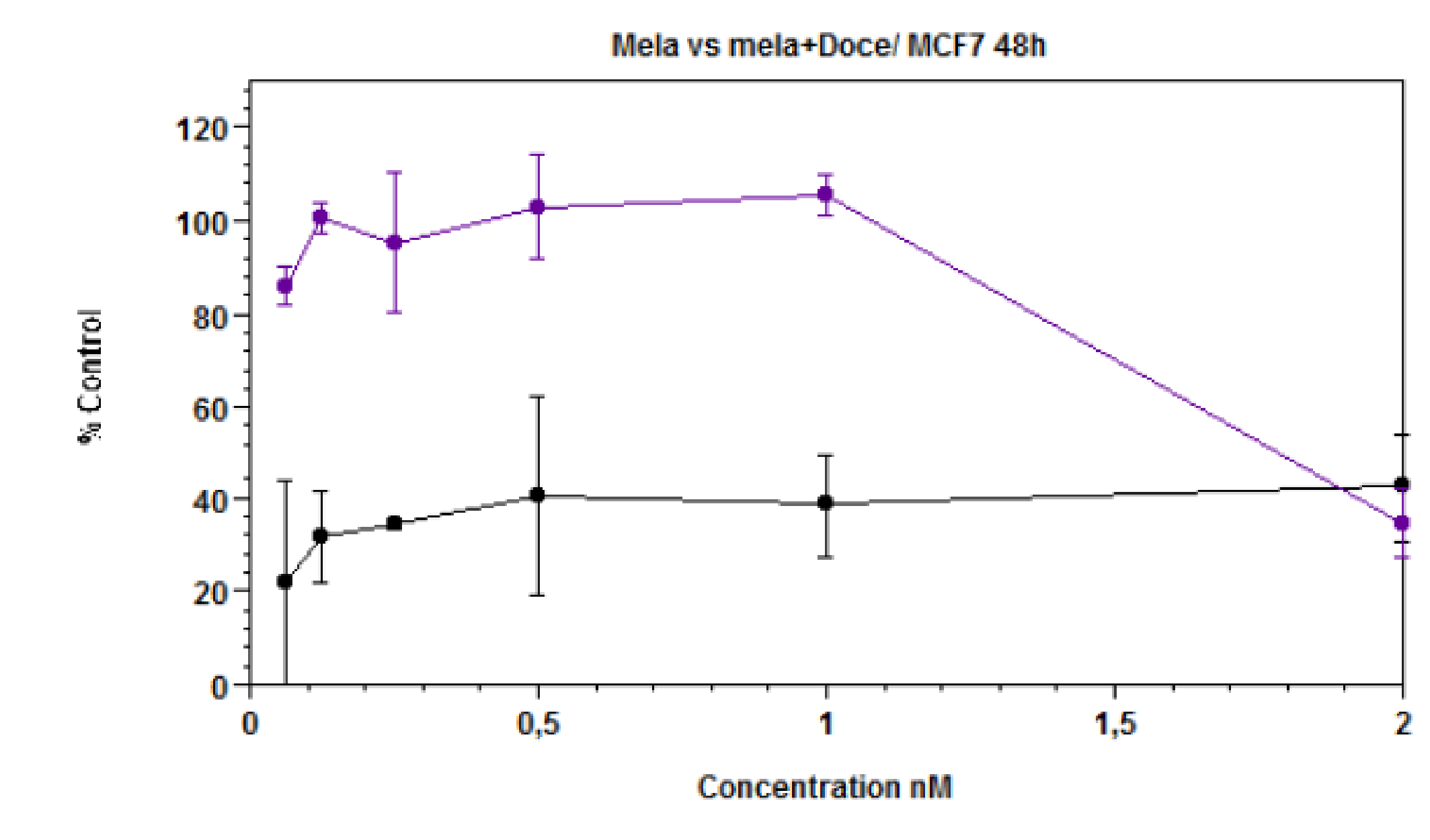

In conclusion, it appears that melatonin exerts an inhibitory effect on the proliferation of breast cancer cells in vitro. These findings should be confirmed in other cell lines and are in agreement with findings of other researchers having shown the presence of the melatonin receptor MT1 (Jablonska et al, Pineal Res 2013) on the cell surface of breast cancer cells.

\section{References}

Jablonska K, Pula B, Zemla A, Owczarek T, Wojnar A, Rys J, Ambicka A, PodhorskaOkolow M, Ugorski M, Dziegiel P. Expression of melatonin receptor MT1 in cells of human invasive ductal breast carcinoma. J Pineal Res 2013; 54:334-45. 